\title{
Influence of Nano-Sized LSCF Cathode and Its Firing Temperature on Electrochemical Performance in Oxygen-Excess-Type Solid Electrolyte (OESE)-Based Fuel Cells
}

Hiroyuki Mieda, ${ }^{a}$ Atsushi Mineshige,${ }^{\mathrm{a}, *}$ Atsushi Saito, ${ }^{\mathrm{a}}$ Tetsuo Yazawa, ${ }^{\mathrm{a}}$ Hideki Yoshioka, ${ }^{\mathrm{b}}$ and Ryohei Mori ${ }^{\mathrm{c}}$

${ }^{a}$ Department of Materials Science and Chemistry, Graduate School of Engineering, University of Hyogo, 2167 Shosha, Himeji, Hyogo 671-2201, Japan

${ }^{b}$ Hyogo Prefectural Institute of Technology, 3-1-12 Yukihira-cho, Suma-ku, Kobe, Hyogo 654-0037, Japan

${ }^{c}$ Fuji Pigment Co., Ltd., 2-23-2 Obana, Kawanishi, Hyogo 666-0015, Japan

*Corresponding author

2167 Shosha, Himeji, Hyogo 671-2201, Japan

+81-79-267-4944 (Phone\&Fax)

mine@eng.u-hyogo.a 


\begin{abstract}
Dense films of an oxygen-excess-type solid electrolyte (OESE) based on Mg-doped lanthanum silicate (MDLS) were fabricated and applied to electrolyte materials for intermediate temperature solid oxide fuel cells (IT-SOFCs). To obtain dense MDLS films on NiO-MDLS porous substrates, a conventional spin-coating technique using the MDLS printable paste, obtained by mixing nano-sized MDLS particles and a dispersant, was employed. The Ni-MDLS anode supported single cells were then fabricated by printing porous cathode layer onto the electrolyte film surface. By optimizing fabrication conditions of an MDLS film and cathode, the highly active cathode/OESE interface $\left(\mathrm{ASR}=0.23 \Omega \mathrm{cm}^{2}\right.$ at $873 \mathrm{~K}$ ) were successfully obtained, which resulted in high power density of $0.166 \mathrm{~W} \mathrm{~cm}^{-2}$ at $873 \mathrm{~K}$ in the fuel cell test when operated with argon-diluted hydrogen and pure oxygen as the fuel and the cathode gas, respectively.
\end{abstract}

\title{
Keywords;
}

Solid oxide fuel cell; Apatite; Lanthanum Silicate; Oxygen-excess Solid Electrolyte 


\section{Introduction}

Oxide ion conducting solid electrolytes are key materials for high temperature electrochemical devices such as solid oxide fuel cells (SOFCs), steam electrolyzers, and sensors. Especially, SOFCs have attracted great interest as high efficient power sources with environmental compatibilities. Although a widely used yttria-stabilized zirconia (YSZ) electrolyte has excellent properties as solid electrolyte at above $1023 \mathrm{~K}$, it does not show practical ionic conductivity at the intermediate-temperature (IT) range $(773-1023 \mathrm{~K})$ because of its slow oxide ion diffusion based on the so-called vacancy mechanism. Operation at high temperatures leads to the situation requiring heat resistive components and consideration for minimizing heat shock or sintering of electrode materials. To overcome these problems, other oxide ion conducting solid electrolytes such as doped ceria [1] and doped lanthanum gallate [2] exhibiting high ionic conductivity even in the IT range have been investigated.

In 1995, a solid oxide electrolyte not relied upon the vacancy mechanism was found by Nakayama et al. [3-5]. This new class of oxide ion conductors are oxygen-excess-type solid electrolytes (OESEs) based on lanthanoid silicates, ${ }^{n}{ }_{9.33+\mathrm{x}} \mathrm{Si}_{6} \mathrm{O}_{26+1.5 \mathrm{x}}$, $(\mathrm{Ln}=\mathrm{La}, \mathrm{Nd}$, etc.) with apatite-type structure. Especially, lanthanum silicate (La9.33+x $\mathrm{Si}_{6} \mathrm{O}_{26+1.5 \mathrm{x}}$ LSO) have been considered as promising electrolytes for IT-SOFCs [6-9]. This OESE material has good features of high ion conductivity, low activation energy for conduction, and high ionic transference number [8]. In 2004, Yoshioka found that slight cation doping such as magnesium or aluminum, into the Si-site was 
found to be effective for the improvement in oxide ion conductivity [10,11]. Although we have already reported that sintered LSO ceramics electrolytes (ca. $0.7 \mathrm{~mm}$ in thickness) had promising SOFC performance (250 and $18 \mathrm{mWcm}^{-2}$ at $1073 \mathrm{~K}$ and $873 \mathrm{~K}$, respectively) [8], the practical use of OESEs for SOFC application is still difficult because of the necessity of high sintering temperature of bulk LSO ceramics $(\geq 1873 \mathrm{~K})$ as well as high ohmic and polarization resistances of the cell. It is necessary to establish the thin film technology to fabricate dense LSO films to decrease its firing temperature and an ohmic resistance of the cell.

Various kinds of thin film growth processes of LSOs have been investigated in the literature such as sol-gel [12], tape-casting [13], and sputtering [14] processes. We have proposed the plasma spraying technique as a good candidate for the fabrication process of Mg-doped lanthanum silicate (MDLS) thin films [15]. The SOFC thus obtained exhibited a maximum power density of 146 and $41 \mathrm{mWcm}^{-2}$ at $1073 \mathrm{~K}$ and $873 \mathrm{~K}$, respectively [16] with conventional cathode, $\left(\mathrm{La} 0.6 \mathrm{Sr}_{0.4}\right)\left(\mathrm{Co}_{0.2} \mathrm{Fe}_{0.8}\right) \mathrm{O}_{3-\delta}$ (LSCF) and NiO-MDLS (6:4 in weight ratio) cermet anode support. Since it is preferable to fabricate dense LSO films in a simple and cost-effective way under lower synthesis temperatures, we have employed the MDLS printable paste obtained by mixing MDLS nano-sized particles and a dispersant, with a conventional spin-coating technique on porous substrates made of $\mathrm{NiO}$ and MDLS particles [16]. The Ni-MDLS anode supported SOFC thus obtained showed a maximum power density of 150 and $14 \mathrm{mWcm}^{-2}$ at $1073 \mathrm{~K}$ and $873 \mathrm{~K}$, respectively, by using $1773 \mathrm{~K}$-sintered MDLS film (15 $\mu \mathrm{m}$ in thickness) with the same LSCF 
cathode and NiO-MDLS (6:4) anode.

In spite of large efforts by us and other research groups, however, high performance ( $>$ ca.

$0.15 \mathrm{~W} \mathrm{~cm}^{-2}$ ) SOFC using the OESE thin film electrolyte has not been reported so far, especially in the IT range. In our previous study using the MDLS printable paste [16], it was found that the polarization resistance of the cell was large $\left(7.3 \Omega \mathrm{cm}^{2}\right.$ at $\left.873 \mathrm{~K}\right)$ compared with the ohmic resistance (3.5 $\Omega \mathrm{cm}^{2}$ at $873 \mathrm{~K}$ ). Hence, to develop high performance OESE-based SOFCs, it is required to design electrode / OESE interface as well. The main cause of high polarization resistance is probably due to a lack of catalytic activity of LSCF cathode and/or its interfacial performances since the total polarization resistance was governed by that of LSCF cathode according to the 3-electrodes measurements [17]. To improve this, it is necessary to optimize fabrication processes of electrode materials. The present study aims at improving the performance of the MDLS-based SOFC by using nano-sized LSCF and inspecting optimum firing temperature of printed LSCF on OESE.

\section{Experimental}

\section{$\underline{\text { 2.1 Preparation of MDLS films on Ni-MDLS anode support }}$}

The nano-sized MDLS printable paste with a composition of $\mathrm{La9.8}\left(\mathrm{Si}_{5.7} \mathrm{Mg}_{0.3}\right) \mathrm{O}_{26.4}$ was 
prepared via conventional solid state reaction, followed by mixing the powder and a dispersant with zircon beads using a milling machine as described elsewhere [16]. To obtain Ni-MDLS anode support, $\mathrm{NiO}$ and MDLS powders were mixed in 6:4 in weight ratio and pressed into disks of 13 $\mathrm{mm}$ in diameter and $1.5 \mathrm{~mm}$ in thickness. In the present study, carboxymethylcellulose was added as a binder to anode substrate. The disks were fired at $1673 \mathrm{~K}$ for $4 \mathrm{~h}$. The nano-sized MDLS printable pastes were spin-coated on the anode supports with a spinning rate of $5000 \mathrm{rpm}$ for $30 \mathrm{~s}$ to fabricate OESE cells. They were dried at $453 \mathrm{~K}$ for $10 \mathrm{~min}$ and then heated at $773 \mathrm{~K}$ for 10 min to burn out organic component. After repeating this procedure for 4 times, the MDLS films on the anode supports were finally sintered for $4 \mathrm{~h}$ at $1773 \mathrm{~K}$. Film structures were examined by a field-emission type scanning electron microscope (SEM, Sirion, FEI company, and JSM-7001F, JEOL) with an acceleration voltage of 5 to $15 \mathrm{kV}$.

\section{$\underline{2.2 \text { Fabrication and evaluation of anode supported SOFC }}$}

The Ni-MDLS anode supported single cells were fabricated by screen-printing LSCF paste to the OESE film surfaces, followed by heating at $1173 \mathrm{~K}$ or $1273 \mathrm{~K}$. The cathode paste was prepared by mixing LSCF powders in terpineol solvent. In the present study, nano-sized LSCF powder (ca. $100 \mathrm{~nm}$ in diameter) was also employed in addition to the conventional LSCF powder (ca. $1 \mu \mathrm{m}$ in diameter). The Pt layers were fabricated by painting Pt paste (TR-7907, Tanaka Kikinzoku Kogyo, Co., Ltd.) on both LSCF and anode faces, and fired again at $1173 \mathrm{~K}$ or $1273 \mathrm{~K}$ to 
ensure the electrical contact. A single cell thus obtained was heated to $1173 \mathrm{~K}$ or $1273 \mathrm{~K}$ to melt Pyrex glass rings for sealing and set down to $1073 \mathrm{~K}$. Pure oxygen and $\mathrm{H}_{2}-\mathrm{Ar}$ mixed gas were supplied to cathode side and anode side, respectively. After open circuit voltage (OCV) got stable, I-V characteristic curves were measured using a galvanostat (HA-151, Hokuto Denko Corp.) and an electrometer (R6452E, Advantest Corp.). AC impedance plots at OCV conditions were measured under an open-circuit condition by an impedance analyzer (760C, ALS Co., Ltd) with frequencies ranging from $100 \mathrm{kHz}$ to $10 \mathrm{mHz}$. These measurements were performed at $873 \mathrm{~K}-1073 \mathrm{~K}$.

\section{Result and Discussion}

\section{$\underline{3.1 \text { Effect of LSCF grain size on properties }}$}

Figure 1 shows fuel cell properties at (a) $873 \mathrm{~K}$ and (b) $1073 \mathrm{~K}$ for three types of anode supported OESE-based SOFCs exhibiting different cathode/OESE interfaces. The Cell A utilized printed LSCF cathode fired at $1273 \mathrm{~K}$, whose grain size was about $1 \mu \mathrm{m}$. In case of the Cells B and C, we employed pulverized LSCF powder with a beads milling process to the averaged grain size of $0.1 \mu \mathrm{m}$, whose chemical composition was the same as that used for the Cell A. The nano-sized LSCF was printed on the MDLS electrolyte and fired at $1273 \mathrm{~K}$ (Cell B) or $1173 \mathrm{~K}$ (Cell C), respectively. The Cell A exhibited the maximum power density $\left(P_{\max }\right)$ of 175 and $44 \mathrm{~mW} \mathrm{~cm}^{-2}$ at 
1073 and $873 \mathrm{~K}$, respectively. The performance was slightly improved by the addition of carboxymethylcellulose as a binder to anode support in this study compared with the previous report [16]. On the other hand, the Cell B showed $P_{\max }$ of 358 and $99 \mathrm{mWcm}^{-2}$ at 1073 and $873 \mathrm{~K}$, respectively, which was much higher than those for the Cell A. This improvement in the fuel cell performance was owing to a decrease in particle size of the LSCF since no experimental conditions were modified except for the size of LSCF particles. The OCVs of the cells were lower than the theoretical values. Since the electrochemical cell using sintered ceramics electrolytes of MDLS showed theoretical OCV values, this result suggested that there was slight gas leakage through the thin electrolyte film of the cell.

Figure 2 shows AC impedance plots at (a) $873 \mathrm{~K}$ and (b) $1073 \mathrm{~K}$ for three cells. Here, we assumed that a high-frequency intersection represents the ohmic resistance, $R_{o h m}$, and a diameter of the semi-arc represents polarization resistance, $R_{p o l}$. The evaluated $R_{o h m}$ and $R_{p o l}$ values in area specific resistance (ASR) expression are listed in Table 1. Taking consideration of ion conductivity of MDLS, the $R_{p o l}$ value seemed to be too high. In the case of $\mathrm{ZrO}_{2}$-based film fabricated by using a spin-coating method, an expected $R_{\text {ohm }}$ value was obtained [18]. This contradiction will be discussed later. From Fig. 2, it was elucidated that the $R_{p o l}$ largely decreased with the introduction of the nano-sized LSCF cathode. This fact showed that the power density was improved due to the reduction in $R_{p o l}$ by introducing nano-sized LSCF.

Although a study on the electrochemical oxygen reduction behavior for LSCF cathode 
applied on the bulk OESE, La9.33+x $\left(\operatorname{Si}_{6-\mathrm{y}} M_{\mathrm{y}}\right) \mathrm{O}_{26+1.5 \mathrm{x}-\mathrm{y}}(M ; \mathrm{Mg}$ or $\mathrm{Al})$, is currently under way, and will be discussed in the future paper in detail, here, it is worth mentioning briefly regarding the expected rate-determining step of our LSCF/OESE electrochemical system. From the study on cathode $R_{p o l}$ of LSCF in the 3-electrodes configuration as a function of oxygen partial pressure at each temperature, it was suggested that the gas diffusion rate through the cathode layer was slower compared with those for other steps such as the charge transfer or oxygen dissociation reactions. From SEM images of the fractured cross sections of three cells after the fuel cell tests for 8 hours as shown in Fig. 3, one may consider that gas diffusion through the cathode layer probably is a rate-determining step owing to a lack of porosity. Hence, it was suggested that gas diffusion through the layer was enhanced by using nano-sized LSCF powder to the cathode layer. According to the magnified cross section image of the Cell (B) [Fig. 3(d)], the diameter of nano-sized LSCF cathode particles was still small. Therefore, an increasing porosity is probably one main reason of the reduction in the polarization resistance.

In addition, it was found that the step for oxygen dissociation also takes part in the rate-determining step at lower temperatures around $873 \mathrm{~K}$ according to the preliminary study. As seen in Table 1, the effect of grain size of LSCF powder on the electrochemical property was significant at lower temperatures. Therefore, the oxygen dissociation step was also improved at lower temperatures by increasing effective reaction zone in case of the nano-sized LSCF cathode. Furthermore, the $R_{o h m}$ values also decreased with the introduction of the nano-sized LSCF cathode 
although the electrolyte thickness of the both cells was similar (ca. $8 \mu \mathrm{m}$ ). It was probably due to the increase in surface area of cathode, resulted in a reduction in contact resistances. Hence, it was concluded that the performance of the SOFC cell could be largely improved due to decreases in the ohmic as well as polarization resistance of the Cell B with increasing the porosity and surface area of cathode .

In SOFCs utilizing conventional oxygen-deficit type solid electrolytes, effects of grain size and pore structure of LSCF or related cathode materials on the electrochemical behavior have been widely investigated [19-22]. Darbandi et al. [19] reported the improved performance by using nanoparticles of LSCF and LBSCF ( $\mathrm{La}_{0.25} \mathrm{Ba}_{0.25} \mathrm{Sr}_{0.5} \mathrm{Co}_{0.2} \mathrm{Fe}_{0.8} \mathrm{O}_{3-\delta}$ ), and concluded that the main reason for the improvement was due to their high specific surface area. In case of the $\mathrm{CeO}_{2}$-based interlayer on YSZ, the $R_{p o l}$ of the nano-sized LSCF cathode ( $1 \mu \mathrm{m}$ in thickness) was around $0.7 \Omega$ $\mathrm{cm}^{2}$ at $873 \mathrm{~K}$ [19]. Philippeau et al. [22] reported that the LSCF cathode $(0.27 \mu \mathrm{m})$ had $R_{p o l}$ of around $0.3 \Omega \mathrm{cm}^{2}$ at $873 \mathrm{~K}$ on the $\operatorname{LSGM}\left(\mathrm{La} 0.8 \mathrm{Sr}_{0.2} \mathrm{Ga}_{0.8} \mathrm{Mg}_{0.2} \mathrm{O}_{3-\delta}\right)$ electrolyte. These facts showed that the ideal cathode/OESE interface could be fabricated in this study by reducing LSCF particle size. Note that, however, the discussion should be basically done with crack-free electrolyte film, showing theoretical OCV, whereas that was not strictly the case in this work. This problem will be solved by using high-viscosity MDLS paste or adding a binder in the future. 


\subsection{Optimization of firing temperature of nano-sized LSCF cathode}

To determine optimum firing temperature of pulverized LSCF cathode, an effect of the firing temperature on the cell performance was investigated by comparing the performance of the cells with nano-sized LSCF fired at $1173 \mathrm{~K}$ (Cell C) with that fired at $1273 \mathrm{~K}$ (Cell B). Although the OCV values were still lower than the theoretical one, the Cell $\mathrm{C}$ exhibited superior SOFC performance to that of the Cell $\mathrm{B}$. That had high power density values of 0.552 and $0.166 \mathrm{Wcm}^{-2}$ at 1073 and $873 \mathrm{~K}$, respectively. This is the first report showing such a high SOFC performance using OESE.

From the AC impedance plots of the Cell C under OCV conditions, both the $R_{o h m}$ and $R_{p o l}$ values of the Cell C largely decreased by decreasing firing temperature toward $1173 \mathrm{~K}$, and were the smallest value compared to that reported in the literature regarding this type of the electrolyte [22,23]. Although the $\mathrm{Ba}_{0.5} \mathrm{Sr}_{0.5} \mathrm{Co}_{0.8} \mathrm{Fe}_{0.2} \mathrm{O}_{3-\delta}$ (BSCF) nano-particles cathode exhibited less than $0.07 \Omega \mathrm{cm}^{2}$ of $R_{p o l}$ at $873 \mathrm{~K}$ on a thin-film doped ceria [21] and showed excellent electrochemical property superior to that of the Cell $\mathrm{C}$, the performance of the Cell $\mathrm{C}$ was still acceptable. These facts indicated that OESE was also able to construct good electrode/electrolyte interface with appropriate electrode materials. The SOFC performance using LSO-based electrolyte is expected to be improved further by optimizing the chemical composition as well as pore structure of the cathode materials to promote the oxygen reduction reaction.

To investigate the reason of the improvement of the interface in the case of the Cell $\mathrm{C}$, 
interfacial structure was examined with SEM-EDX microanalysis. Figure 4 shows elemental profiles of lanthanum, silicon and iron across the interface between nano-sized cathode firing at different temperatures, and the MDLS electrolyte. In the case of the $1273 \mathrm{~K}$-fired cell, diffusion of Si from electrolyte towards cathode was observed as already reported by Tsipis et al. [24] and Yaremchenko et al. [25]. They suggested that Si-containing surface layer formed by minor Si diffusion, might block the electrochemical reaction zone. This might be one reason of high ohmic and polarization resistance of cells. On the other hand, the concentration of Si changed steeply at the electrode/electrolyte interface in the case $1173 \mathrm{~K}$-fired specimen, implying that Si diffusion was suppressed by reducing the firing temperature. According to Fig. 4, the La element showed somewhat a similar behavior to the $\mathrm{Si}$ element, that is, the concentration change was gentle and steep across the interface for the $1273 \mathrm{~K}$ - and $1173 \mathrm{~K}$-fired cell, respectively. It should be noted that there is a large difference in La activity at MDLS and LSCF interface. This might be a driving force of $\mathrm{La}$ and $\mathrm{Si}$ diffusion when the firing process above $1273 \mathrm{~K}$. Hence, reduction in the firing temperature of LSCF toward $1173 \mathrm{~K}$ was effective to reduce the contact resistance between two solids and to enhance the effective reaction area, resulted in the reduction in both $R_{o h m}$ and $R_{p o l}$ values. Therefore, it was concluded that the fabrication conditions of the Cell $\mathrm{C}$ was the most preferable.

The ionic conductivity of the Cell $\mathrm{C}$ was estimated at $1.9 \times 10^{-3}$ and $0.8 \times 10^{-3} \mathrm{~S} \mathrm{~cm}^{-1}$ at 1073 and $873 \mathrm{~K}$, respectively, if $R_{o h m}$ was equal to the electrolyte resistance. Although $R_{o h m}$ could be 
minimized by optimizing fabrication conditions, the evaluated resistance was still larger than expected from the conductivity of MDLS ceramics sintered at $1973 \mathrm{~K}$ [16]. The firing temperature higher than $1873 \mathrm{~K}$ might be a prerequisite for obtaining high conductive MDLS. Although further studies are necessary to reduce the ohmic loss of the cell, and to improve the MDLS film density, it is concluded that the MDLS pasted film electrolyte is a promising candidate for the electrolyte material of the IT-SOFCs.

\section{Conclusion}

With optimizing fabricating conditions of cathode materials, the high performance OESE-based SOFC was developed. The cell, nano-sized LSCF/MDLS/Ni-MDLS showed a maximum power density of 0.552 and $0.166 \mathrm{Wcm}^{-2}$ at 1073 and $873 \mathrm{~K}$, respectively. Since the nano-sized LSCF fired at $1173 \mathrm{~K}$ exhibited good electrochemical properties for the oxygen reduction reaction in the MDLS-based SOFC, it is expected that the high performance IT-SOFCs will be developed using the LSO-based OESE by applying current technologies for fabricating oxygen-deficit type solid electrolyte-based SOFCs. 


\section{Acknowledgements}

This work is supported by Japan Science and Technology Agency (JST), A-step Feasibility

Study Program (\#AS232Z02865C) and A-step Full-Scale R\&D (High-risk challenge) Program

(\#AS2524056L).

\section{References}

[1] B. C. H. Steele, Solid State Ionics, 129, 95 (2000).

[2] T. Ishihara, H. Matsuda, and Y. Takita, J. Am. Chem. Soc., 116, 3801 (1994).

[3] S. Nakayama, H. Aono and Y. Sadaoka, Chem. Lett. 24,431 (1995).

[4] S. Nakayama, T. Kageyama, H. Aono, and Y. Sadaoka, J. Mater. Chem., 5, 1801 (1995).

[5] S. Nakayama, and M. Sakamoto, J Eur. Chem. Soc., 18, 1413 (1998).

[6] H. Yoshioka and S. Tanase, Solid State Ionics, 176, 2395 (2005).

[7] A. Mineshige, T. Nakao, M. Kobune, T. Yazawa and H. Yoshioka, Solid State Ionics, 179 , 1009 (2008).

[8] A. Mineshige, T. Nakao, Y. Ohnishi, R. Sakamoto, Y. Daiko, M. Kobune, T. Yazawa, H. Yoshioka,

T. Fukutsuka, and Y. Uchimoto, J. Electrochem. Soc., 157, 10, B1465 (2010).

[9] H. Arikawa, H. Nishiguchi, T. Ishihara and Y. Takita, Solid State Ionics, 136-137, 31 (2000).

[10] H. Yoshioka, Chem. Lett. 33, 392 (2004). 
[11] H. Yoshioka, Y. Nojiri, and S. Tanase, Solid State Ionics, 179, 2165 (2008).

[12] Y. Masubuchi, M. Higuchi, T. Takeda, S. Kikkawa, J. Allloys and Compounds, 408-412, 641 (2006).

[13] I. Santacruz, J. M. Porras-Vazquez, E. R. Losilla, and M. A. G. Aranda, J. Eur. .Ceram. Soc., 31, 1573 (2011).

[14] C. Y. Ma, P. Briois, J. Bohlmark, F. Lapostolle, and A. Billard, Ionics., 14, 471 (2008).

[15] H. Yoshioka, T. Mitsui, A. Mineshige and T. Yazawa, Solid State Ionics, 181, 1707 (2010).

[16] H. Yoshioka, H. Mieda, T. Funahashi, A. Mineshige, T. yazawa and R. Mori, J. Eur. ceram. Soc. 34, 373 (2014).

[17] X. Xu, C. Xia, S. Huang, and D. Peng, Ceramics International, 31, 1061 (2005).

[18] T. Mitsui, A. Mineshige, T. Funahashi, H. Mieda, Y. Daiko, M. Kobune, H. Yoshioka and T. Yazawa, J. Power Sources, 217, 170 (2012).

[19] A. J. Darbandi and H. Hahn, Solid State Ionics, 180, 1379 (2009).

[20] Y. Chen, Q. Liu, Z. Yang, F. Chen and M. Hanm RSC Advances, 2, 12118 (2012).

[21] Z. Shao and S. M. Haile, Nature, 431, 170-173 (2004).

[22] B. Philippeau, F. Mauvy, C. Mazataud, S. Fourcade, and J-C. Grenier, Solid State Ionics, 249-250, 17 (2013).

[23] D. Marrero-Lopez, M. C. Martin-Sedeno, J. pena-Martinez, J. C. Ruiz-Morales, P. Nunez, M. A. G.. Aranda, and J. R. Ramnos-Barrado, J Power. Sources, 195, 2496 (2010).

[24] E. V. Tsipis, V. V. Kharton, and J. R. Frade, Electrochimica Acta, 52, 4428 (2007). 
[25] A. A. Yaremchenko, V. V. Kharton, D. O. Bannikov, D. V. Znosak, J. R. Frade, and V. A. Cherepanov, Solid State Ionics, 180, 878 (2009). 
TABLE I. Fuel cell performances and electrochemical properties of Cells A, B and C.

\begin{tabular}{ccccccccccccc}
\hline & \multicolumn{3}{c}{$\mathrm{P}_{\max } / \mathrm{mW} \mathrm{cm}^{-2}$} & \multicolumn{3}{c}{$\mathrm{OCV} / \mathrm{mV}$} & \multicolumn{3}{c}{$\mathrm{R}_{\text {ohm }} / \Omega \mathrm{cm}^{2}$} & \multicolumn{3}{c}{$\mathrm{R}_{\text {pol }} / \Omega \mathrm{cm}^{2}$} \\
\cline { 2 - 12 } & $1073 \mathrm{~K}$ & $973 \mathrm{~K}$ & $873 \mathrm{~K}$ & $1073 \mathrm{~K}$ & $973 \mathrm{~K}$ & $873 \mathrm{~K}$ & $1073 \mathrm{~K}$ & $973 \mathrm{~K}$ & $873 \mathrm{~K}$ & $1073 \mathrm{~K}$ & $973 \mathrm{~K}$ & $873 \mathrm{~K}$ \\
\hline $\mathrm{A}$ & 175 & 128 & 44 & 904 & 959 & 969 & 1.4 & 1.7 & 3.2 & 0.30 & 0.46 & 1.5 \\
$\mathrm{~B}$ & 358 & 209 & 99 & 851 & 923 & 900 & 1.2 & 1.5 & 2.0 & 0.15 & 0.19 & 0.42 \\
$\mathrm{C}$ & 552 & 326 & 166 & 867 & 897 & 910 & 0.68 & 1.1 & 1.5 & 0.11 & 0.15 & 0.23 \\
\hline
\end{tabular}




\section{Figure captions}

Fig. 1. Fuel cell properties of Cells A, B and C at (a) $873 \mathrm{~K}$ and (b) $1073 \mathrm{~K}$.

Fig. 2. AC impedance plots of Cells A, B and C at (a) $873 \mathrm{~K}$ and (b) $1073 \mathrm{~K}$.

Fig. 3. SEM images of fractured cross sections of (a) Cell A, (b) Cell B, and (c) Cell C after fuel cell test for 8 hours ( $\times 5000$ magnification); (d) $\times 10000$ magnified cross section of Cell B.

Fig. 4. SEM images and line profiles of some elements for cathode/OESE interfaces; (a) 1273 K-fired cathode (Cell B) and (b) $1173 \mathrm{~K}$-fired cathode (Cell C). 
(a)

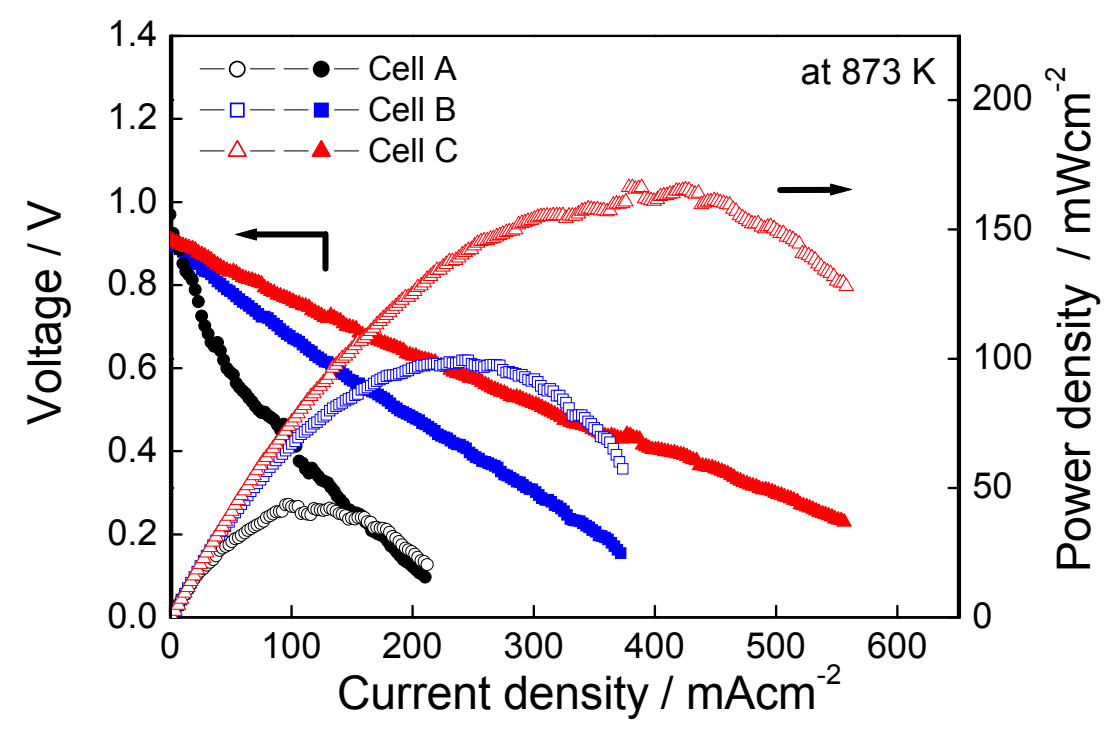

(b)

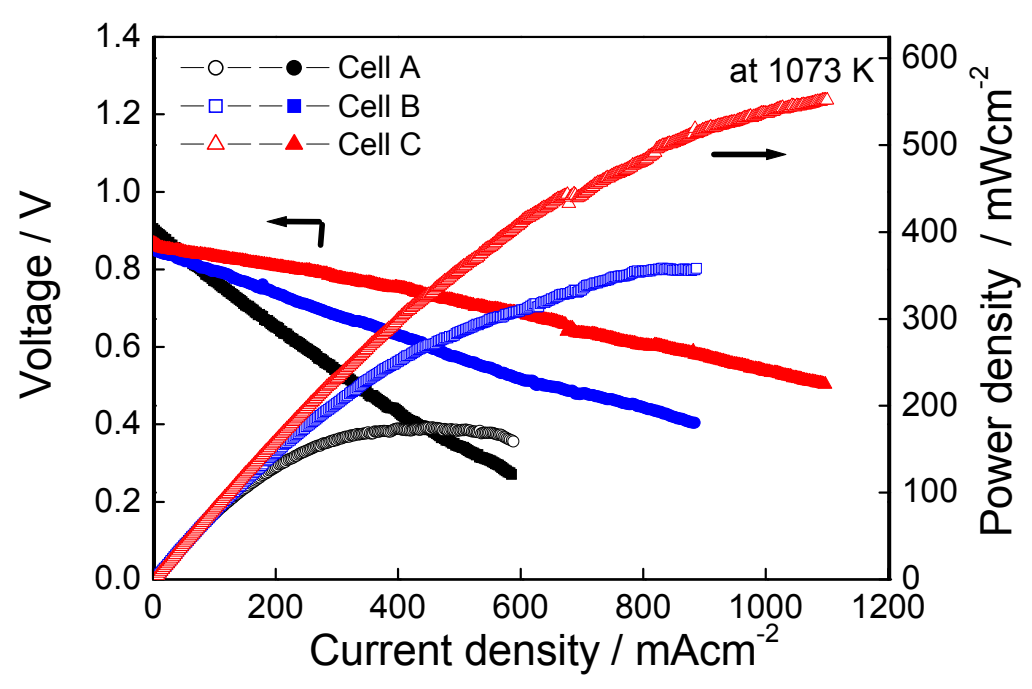

H. Mieda et al., Figure 1 
(a)

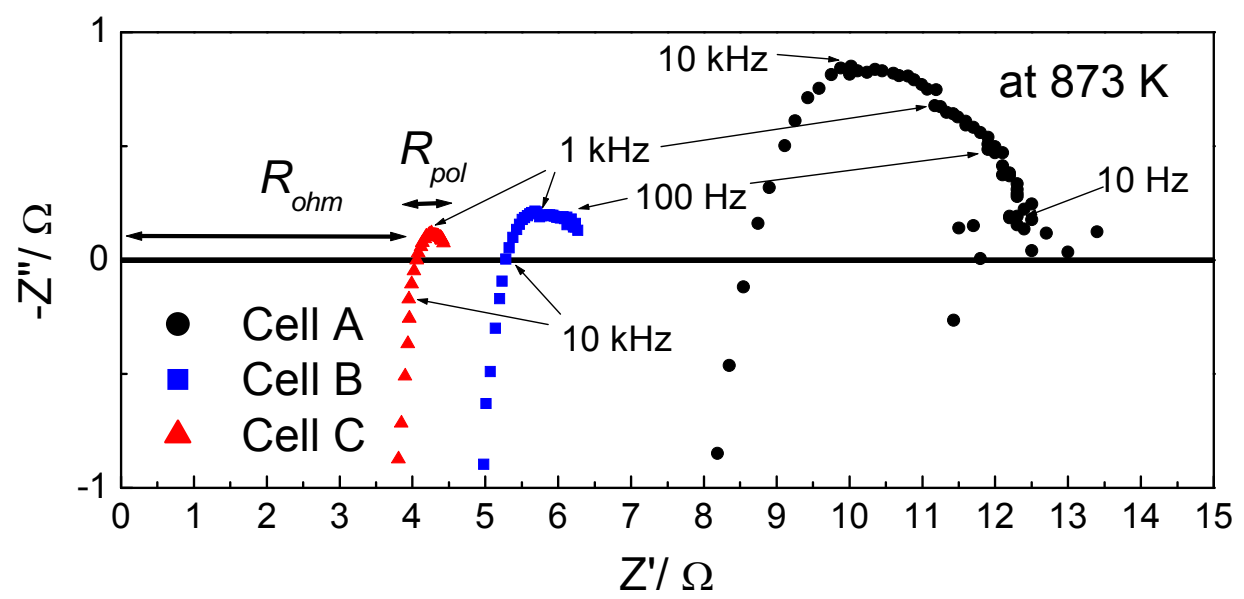

(b)

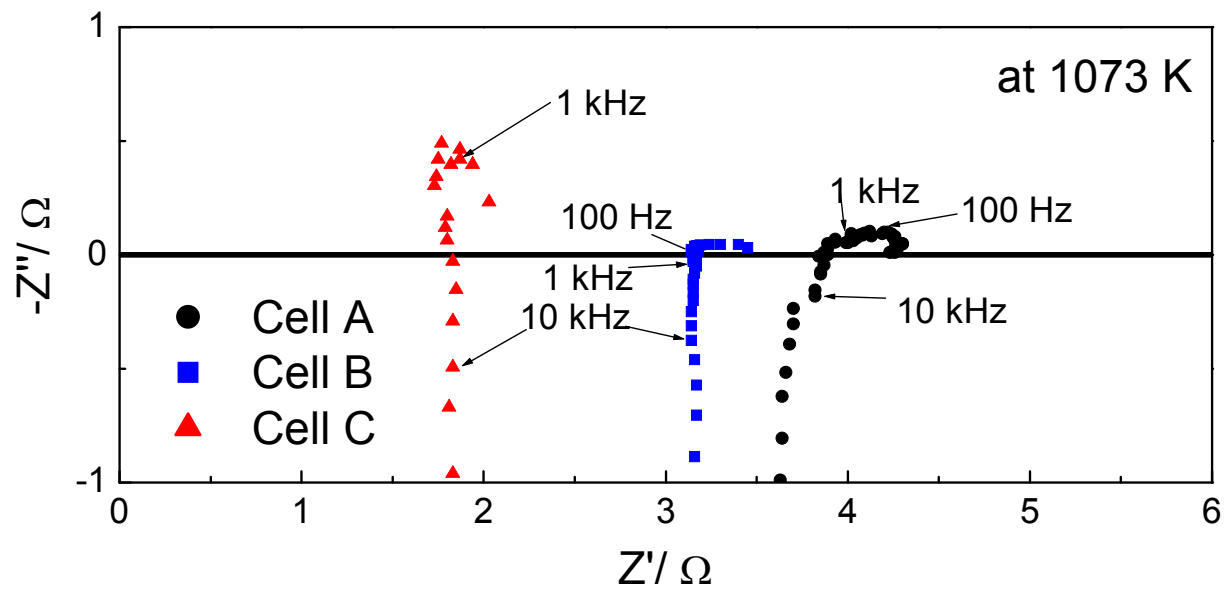

H. Mieda et al., Figure 2 
(a)

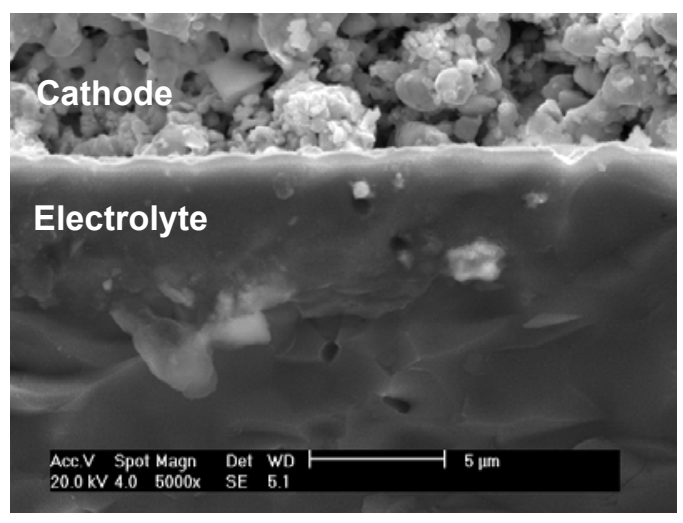

(c)

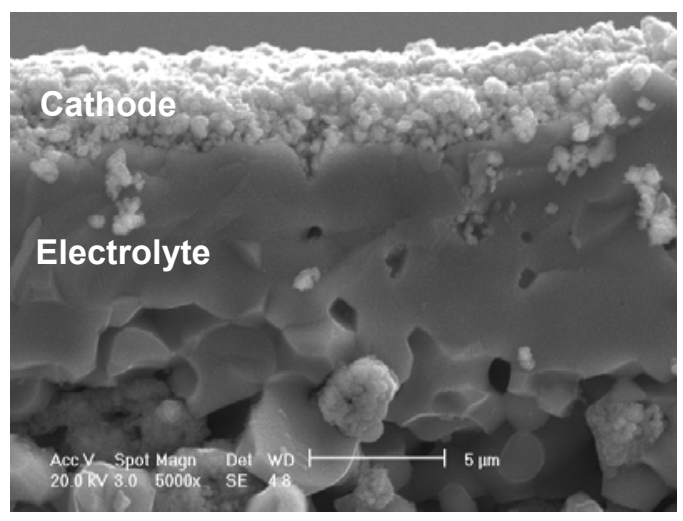

(b)

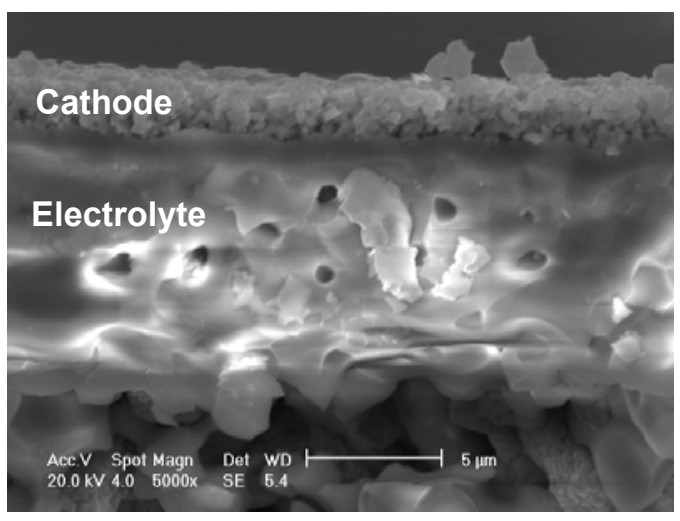

(d)

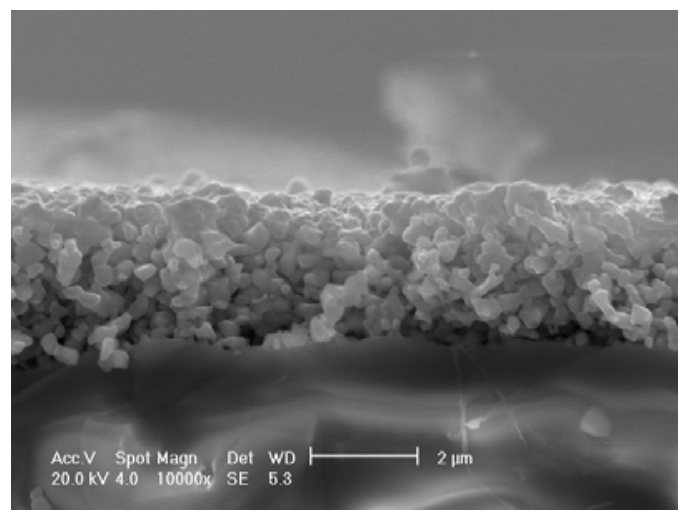

H. Mieda et al., Figure 3 
(a)
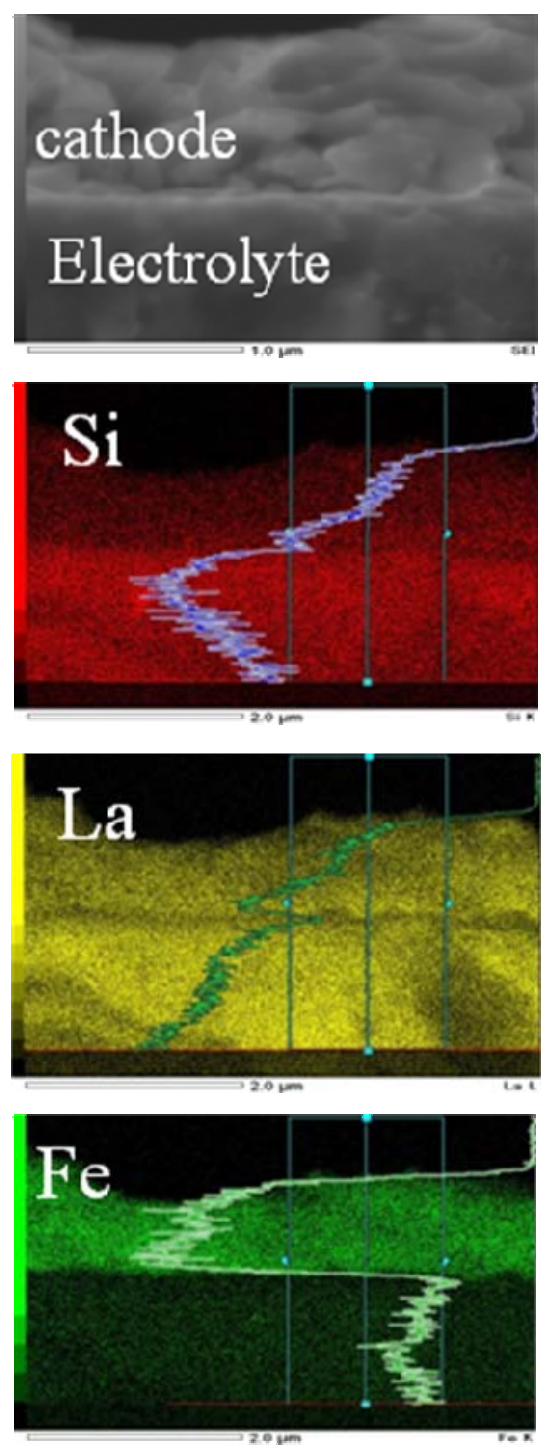

(b)
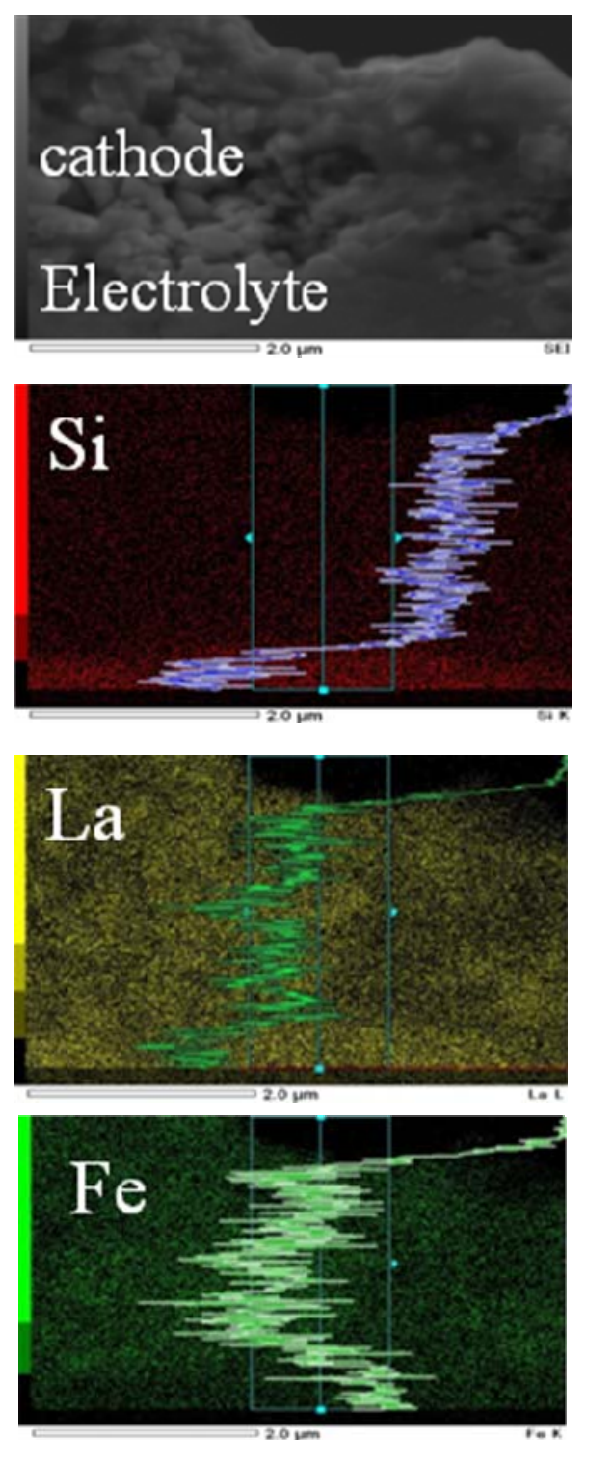

H. Mieda et al., Figure 4 